\title{
EDUKASI MASYARAKAT NELAYAN MELALUI PENGEMBANGAN PRODUK OLAHAN IKAN BERNILAI EKONOMIS TINGGI
}

\author{
Agus Apriyanto*1 $^{* 1}$ Muh. Thohirin ${ }^{2}$, Ahmad Baqi Romadhoni ${ }^{3}$, Aldi Suryansyah ${ }^{4}$ \\ 1,2,3,4 Universitas Sang Bumi Ruwa Jurai \\ e-mail: *1agus.apriyanto89@gmail.com
}

\begin{abstract}
Abstrak
Produk perikanan menyediakan 54 persen dari seluruh protein hewani yang dikonsumsi masyarakat. Meskipun peranannya yang cukup besar, tidaklah demikian dengan kondisi kehidupan nelayan dan keluarganya. Masyarakat nelayan turut menyumbang 25 persen angka kemiskinan nasional pada 2017. Gambaran ini tentu menjadi karakteristik spesifik kerentanan nelayan dalam konteks sosial-ekonomi, khususnya dalam menghadapi Pandemi Covid-19 saat ini. Pandemi Covid-19 telah mempengaruhi keberlangsungan aktivitas produksi dan pemasaran hasil perikanan masyarakat nelayan khususnya di Desa Muara Gading Mas Kecamatan Labuhan Maringgai, Kabupaten Lampung Timur. Peserta pelatihan adalah masyarakat nelayan khususnya ibu-ibu nelayan di Desa Muara Gading Mas untuk melakukan diversifikasi olahan ikan seperti bakso ikan, kerupuk ikan, pindang presto dan pangsit ikan. Kegiatan pengabdian dilakukan tahap demi tahap mulai dari sosialisasi program, survey terkait ketersedian sumber daya alam local, melakukan edukasi sampai dengan demonstrasi terbimbing kepada ibu-ibu nelayan. Hasil pelaksanaan program kegiatan pengabdian kepada masyarakat adalah teredukasinya masyarakat nelayan melalui pengembangan produk olahan ikan bernilai ekonomis tinggi di Desa Muara Gading Mas Kec. Labuhan Maringgai Kab. Lampung Timur dan membuat masyarakat nelayan mampu melakukan diversifikasi produk olahan ikan yang bernilai ekonomis lebih tinggi sehingga mampu menaikan pendapatan ekonomi masyarakat dimasa pandemi.
\end{abstract}

Kata kunci : Ekonomis Tinggi, Masyarakat Nelayan, Produk Olahan Ikan.

\begin{abstract}
Fishery products provide 54 percent of all animal protein consumed by the public. Although their role is quite large, this is not the case with the living conditions of fishermen and their families. The fishing community also contributed to 25 percent of the national poverty rate in 2017. This picture is certainly a specific characteristic of the vulnerability of fishermen in the socio-economic context, especially in the face of the current Covid-19 pandemic. The Covid-19 pandemic has affected the sustainability of the production and marketing activities of fishery communities, especially in Muara Gading Mas Village, Labuhan Maringgai District, East Lampung Regency. The training participants are fishing communities, especially fisherwomen in Muara Gading Mas Village to diversify processed fish such as fish balls, fish crackers, pindang presto and fish dumplings. Service activities are carried out step by step starting from program socialization, surveys related to the availability of local natural resources, conducting education to guided demonstrations to fishermen's mothers. The result of the implementation of the community service activity program is the education of the fishing community through the development of processed fish products with high economic value in Muara Gading Mas Village, Kec. Labuhan Maringgai Kab. East Lampung and enabling fishing communities to diversify processed fish products with higher economic value so that they can increase the economic income of the community during the pandemic.
\end{abstract}

Keywords : High Economist, Fishing Community, Processed Fish Products. 


\section{PENDAHULUAN}

Hasil laut yang melimpah berupa ikan merupakan potensi yang besar untuk dikembangkan dalam menopang perokonomian dan meningkatkan kesejahteraan masyarakat [1] Desa Muara Gading Mas. Tingginya produksi perikanan, menyebabkan rendahnya harga ikan dan berdampak terhadap menurunnya pendapatan masyarakat, namun saat produksi ikan menurun maka harga ikan menjadi mahal dan terkadang masyarakat kesulitan dalam memperoleh ikan sebagai bahan konsumsi keluarga.

Ikan sebagai hasil tangkap masyarakat nelayan Desa Muara Gading Mas umumnya hanya dijual dalam bentuk ikan segar di Tempat Pelelangan Ikan (TPI) dan kadang-kadang sisanya dikeringkan atau dibuat ikan asap. Namun kendala yang muncul adalah jarak tempuh penjualan ke Kota Kabupaten Lampung Timur (Sukadana) sekitar $45 \mathrm{~km}$ dan dari Ibu kota Provinsi Lampung (Bandar Lampung) yang cukup jauh berjrak sekitar $135 \mathrm{~km}$, sehingga biaya transportasi lebih mahal dibandingkan dengan harga jual ikan. Jika ikan diolah menjadi ikan kering ataupun asap, maka muncul rasa bosan bagi konsumen karena tidak ada variasi dalam produk olahan ikan [2]. Variasi produk olahan ikan sangat penting untuk meningkatkan nilai jual dan standar selera konsumen sehingga tidak bosan dengan produk yang sudah ada sebelumnya [3]. Selama ini masyakarat Desa
Muara Gading Mas, belum pernah mendapatkan pelatihan ataupun penyuluhan tentang pengolahan ikan pasca tangkap menjadi produk olahan selain ikan asap dan ikan kering. Ikan merupakan bahan pangan dengan kandungan gizi yang sangat tinggi, khususnya kandungan protein yang sangat baik untuk pertumbuhan dan kecerdasan. Kebanyakan anak-anak di Indonesia sangat malas makan ikan dalam bentuk aslinya, padahal Indonesia terkenal sebagai lumbung ikan dunia [3]. Kurangnya minat makan ikan anakanak Indonesia, mengakibatkan adanya penderita gizi protein dan penghambatan pertumbuhan. Ikan dapat diolah menjadi berbagai macam produk olahan seperti: kerupuk ikan, bakso ikan, dan nugget ikan dengan nilai gizi serta jual yang tinggi.

Corona Virus Disease 2019 (COVID-19) sebagai pandemi telah dideklarasikan oleh World Health Organization (WHO) atau Badan Kesehatan Dunia sejak Maret 2020, yang berarti virus ini telah menyebar secara luas di dunia. Setelah itu, Keputusan Presiden Nomor 12 Tahun 2020 ditetapkan sebagai strategi menanggulangi penyebaran Pandemi COVID-19 yang disebutkan sebagai bencana nasional. Pandemi Covid-19 telah ditetapkan sebagai bencana nasional oleh pemerintah [4] karena tidak hanya sistem kesehatan dan layanan kegawatdaruratan diuji secara luar biasa, namun pada kondisi risiko dan juga dampak terhadap kehidupan masyarakat secara umum.

Pandemic Covid-19 memberikan dampak 
terhadap sektor kelautan dan perikanan yaitu menurunnya harga ikan di beberapa wilayah [5]. Rantai pasok komoditas perikanan terjadi penurunan permintaan ekspor di Indonesia sebesar 10-20 persen. Kondisi ini disebabkan banyak restoran tutup dan kebijakan pembatasan ekspor di berbagai negara, seperti di Amerika Serikat dan Tiongkok [6]. Sebanyak 26.675 Rumah Tangga Perikanan (RTP) terdampak COVID-19, baik karena harga ikan yang anjlok maupun pemasaran untuk ekspor yang tertutup. Selain itu, kebijakan penutupan beberapa daerah juga mempengaruhi penyerapan hasil produksi perikanan para nelayan. Nelayan di beberapa daerah mengalami kesulitan dalam menjual ikan dan mendapatkan harga yang pantas.

\section{METODE}

\subsection{Metode yang Digunakan}

Metode pelaksanaan program Pengabdian Kepada Masyarakat (PKM) dalam kegiatan edukasi masyarakat nelayan melalui pengembangan produk olahan ikan bernilai ekonomis tinggi di Desa Muara Gading Mas Kec. Labuhan Maringgai Kab. Lampung Timur ini berupa pelatihan dan pendampingan pada aspek teknis penatalaksanaan pembuatan produk olahan ikan lainya dan aspek pemasaran.

Selain pendampingan, pengabdian ini akan memberikan skill atau keterampilan kepada kaum ibu-ibu nelayan di Desa Muara Gading Mas untuk melakukan diversifikasi olahan ikan, seperti: dibuat menjadi kerupuk, nugget, otakotak, atau dapat juga dibuat menjadi dendeng sehingga produk yang dihasilkan lebih tahan lama dan bisa menjadi cikal bakal produk unggulan selain ekspor daging ikan tuna. Adanya pengabdian masyarakat ini, diharapkan agar kondisi dampingan, khususnya kaum ibu-ibu nelayan akan lebih baik dalam hal pengetahuan dan keterampilan dalam mengolah limbah ikan dan diharapkan dapat membantu perekonomian keluarga tanpa meninggalkan tugas utamanya sebagai seorang istri dan ibu bagi anak-anak mereka.

Adapun tahapan tahapannya adalah:

1. Sosialisasi program pengabdian untuk menyatukan persepsi tim pengusul dan mitra dalam pelaksanaan program.

2. Melakukan survey tentang ketersediaan sumber daya alam local dan sumber daya manusia yang akan dijadikan sebagai masyarakat sasaran pendampingan dan pelatihan dalam mengolah ikan menjadi aneka jenis produk makanan yang bernilai gizi dan ekonomi tinggi.

3. Melaksanakan strategi untuk mencapai kondisi yang diharapkan. Strategi yang pertama dilakukan adalah dengan mengajak ibu-ibu nelayan untuk bergabung dalam program pengabdian ini, yaitu 
mereka akan dibentuk menjadi kelompok binaan.

4. Melakukan edukasi atau penyuluhan tentang manfaat ikan dalam bidang kesehatan maupun sebagai bahan dasar dalam pembuatan aneka jenis makanan olahan yang bernilai gizi dan ekonomi.

5. Melakukan demonstrasi terbimbing dan praktikum untuk memberikan keterampilan kepada para peserta latihan dalam mengolah ikan menjadi aneka produk makanan, yang nantinya akan didampingi oleh tutorial (pendamping praktikum) dalam membuat sampai mengasilkan produk.

6. Setelah produk dihasilkan, maka selanjutnya dilakukan pengujian keamanan pangan, dan selanjutnya dilakukan pendampingan dalam pengemasan dan pemasaran produk.

\subsection{Jadwal Kegiatan}

Pengabdian ini dilakukan mulai dari bulan Maret 2021 sampai dengan bulan April 2021.

Tabel 1. Rencana Kegiatan

\begin{tabular}{|c|c|c|c|c|c|c|c|c|c|}
\hline \multirow{2}{*}{ No. } & \multirow{2}{*}{ Kegiatan } & \multicolumn{4}{|c|}{ Maret } & \multicolumn{4}{|c|}{ April } \\
\hline & & 1 & 2 & 3 & 4 & 5 & 6 & 7 & 8 \\
\hline \multirow{3}{*}{1} & Pengurusan & & & & & & & & \\
\hline & Kerjasama dengan & & & & & & & & \\
\hline & Mitra & & & & & & & & \\
\hline 2 & Tahap 1 & & & & & & & & \\
\hline 3 & Tahap 2 & & & & & & & & \\
\hline
\end{tabular}

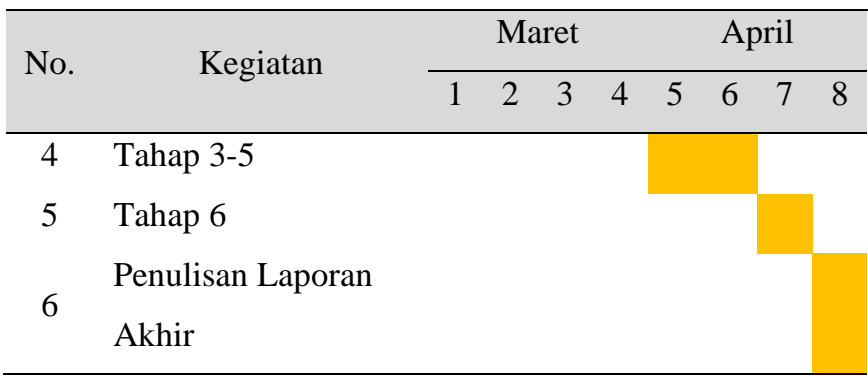

\section{HASIL DAN PEMBAHASAN}

Berdasarkan analisis situasi yang dihasilkan dari kegiatan survey awal di Desa Muara Gading Mas Kecamatan Labuhan Maringgai Kabupaten Lampung Timur, diketahui bahwa masyarakat nelayan di daerah tersebut mengalami penurunan pendapatan karena merosotnya harga ikan segar di tempat pelelangan ikan. Hal tersebut merupakan akibat dari pandemi Covid 19 yang melanda saat ini, hasil tangkapan ikan nelayan tidak dapat dipasarkan secara maksimal karena adanya pemberlakukan pembatasan ruang gerak masyarakat ditengah pandemi. Sementara disisi lain hasil tangkapan ikan para nelayan cukup banyak dan susah untuk pendistribusian dan menjual hasil ikannya.
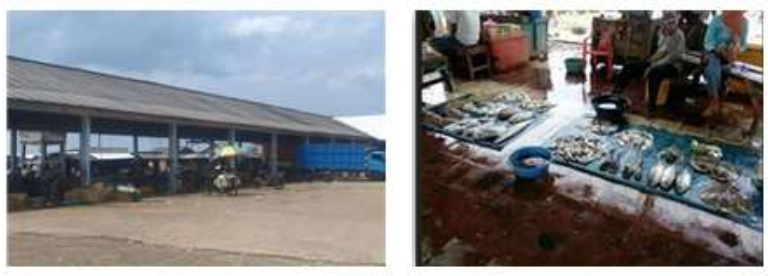

Gambar 1. Situasi Aktivitas TPI Muara Gading Mas 
Kegiatan pengabdian bertujuan mengedukasi masyarakat nelayan melalui pengembangan produk olahan ikan bernilai ekonomis tinggi diharapkan masyarakat nelayan mampu melakukan diversifikasi produk olahan ikan yang bernilai ekonomis lebih tinggi sehingga mampu menaikan pendapatan ekonomi masyarakat dimasa pandemi.

Pada kegiatan pertama yang dilakukan adalah pelatihan, para ibu-ibu mendapat pelatihan dan keterampilan untuk melakukan diversifikasi olahan ikan, seperti: dibuat menjadi kerupuk, nugget, otak-otak, atau dapat juga dibuat menjadi dendeng sehingga produk yang dihasilkan lebih tahan lama dan bisa menjadi cikal bakal produk unggulan. Pada pelaksanaan pelatihan nampak sekali ibu-ibu sangat antusias mengikuti kegiatan tersebut karena mereka menganggap kegiatan ini sangat penting dan dapat memberikan informasi terbaru bagi mereka dalam membuat olahan ikan yang bernilai ekonomis tinggi. Para peserta pelatihan nampak aktif, dan terjadi interaksi dua arah dalam pelatihan ini. Kegiatan pelatihan ini diikuti sekitar 15 partisipan yang terbagi dalam 3 kelompok binaan. Beberapa jenis produk olahan yang dilakukan pelatihan pada kesempatan ini antara lain:

\subsection{Pembuatan Bakso Ikan}

\section{Alat dan Bahan:}

Peralatan dan bahan yang dibutuhkan antara lain : pisau, food processor, alat pemasak, sendok dan sarung tangan plastik. Sementara untuk bahan baku yag disiapkan diantaranya : 1 kg Ikan Tenggiri segar, 2 sendok teh garam, 2 sendok teh kaldu ayam bubuk (pengganti msg), 1 sendok teh bubuk bawang putih, dan $1 / 2$ sendok teh lada.

\section{Proses pembuatan:}

Bakso ikan merupakan produk yang mengandalkan kekuatan gel sebagai indicator mutunya, sehingga dalam pembuatannya harus memperhatikan hal-hal yang dapat mempertahankan dan meningkatkan kekuatan gel. Pemihinan bahan baku ikan, kesegaran ikan dan perlakukan selama proses pengolahan akan sangat menentukan kualitas produk. Urutan dari proses pembuatan Bakso Ikan Tenggiri sebagai berikut : Pertama-tama bahan baku yang sudah disiapkan dicampur menjadi satu kemudian diblender menggunakan food processor sampai halus, kemudian tambahkan 80 gram tepung tapioka dalam adonan. Setelah itu, bentuk adonan menjadi pentol bakso menggunakan sarung tangan plastik dan sendok. Terakhir rendam dalam air panas dan rebus hingga matang dan bakso ikan tenggiri siap dihidangkan atau dipacking ketika akan dipasarkan ketokotoko. 

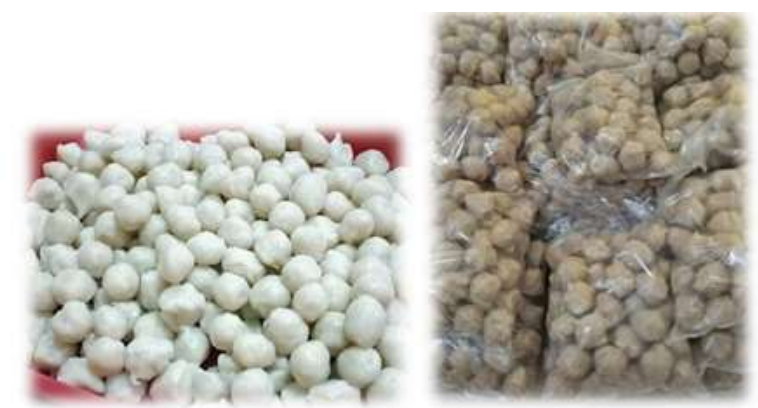

Gambar 2. Bakso Ikan Tenggiri

\subsection{Pembuatan Kerupuk Ikan}

\section{Alat dan Bahan:}

Peralatan dan bahan yang dibutuhkan antara lain : pisau, blender, alat pemasak, sendok, waskom. Sementara untuk bahan baku yag disiapkan diantaranya : $1 / 2 \mathrm{~kg}$ Ikan Tenggiri, 13 sendok makan tepung tapioca, $1 / 2$ sendok teh soda kue, 1 butir telur, 1 butir kuning telur, bumbu -bumbu antara lain: 1/2 sendok teh garam, penyedap rasa dan 1 sendok makan gula pasir.

\section{Proses Pembuatan:}

Langkah pertama blender daging Ikan Tenggiri tanpa kulit dan duri, kemudian kocok telur dan kuning telur. Kemudian langkah kedua campurkan bumbu kedalam telur aduk hingga rata kemudian masukan ikan yang sudah diblender lalu diberi soda kue dan tepung terigu sedikit demi sedikit, kemudian diaduk hingga kalis, kemudian bentuk sekecil mungkin, karena akan mengembang jika digoreng. Setelah dibentuk kemudian digoreng dalam penggorengan dan terakhir adalah packing (pengepakan)
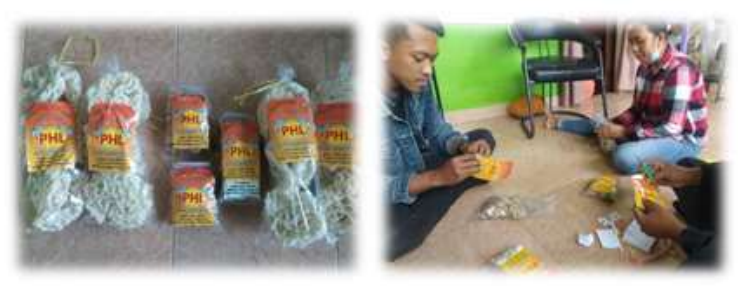

Gambar 3. Kerupuk Ikan Tenggiri

\subsection{Pembuatan Pindang Presto}

\section{Alat dan Bahan:}

Peralatan dan bahan yang dibutuhkan antara lain : panci presto (pressure coocker), layah, parut, talenan, pisau, panci, waskom, kompor gas, daun pisang. Sementara untuk bahan baku yag disiapkan diantaranya : Ikan Bandeng, bawang putih, kunyit, lengkuas, jahe, garam, serai, dun salam.

\section{Proses Pembuatan:}

Pertama ikan disiangi dan dicuci bersih.Bawang putih dan garam dihaluskan, kemudian haluskan juga kunyit, jahe dan lengkuas dan peras airnya dan selanjutnya ditambahkan ke garam dan bawan halus tadi. Renndamlah ikan dalam bumbu selama 6 jam. Panaskan air dalam panic presto yang telah dibubuhi daun salam dan serai. Masukan ikan kedalamnya atur ikan secara berselang seling dengan dilapisi daun pisang. Kukus selama 1-1,5 jam. Setelah masak angkat dan dinginkan. Selanjutnya dilakkan pengemasan 

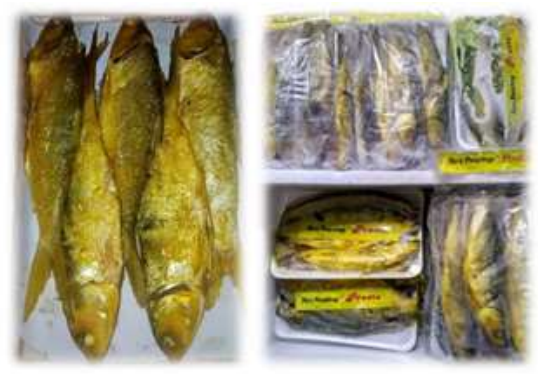

Gambar 4. Pindang Presto Ikan Bandeng

\subsection{Pembuatan Pangsit Ikan}

\section{Alat dan Bahan:}

Peralatan dan bahan yang dibutuhkan antara lain : pisau, talenan, alat penggiling daging/blender,waskom, alat pemasak/panci, alat penggoreng, ikan tenggiri segar, pangsit, wortel, daun bawang, bawang bombay, tepung tapioka, lada, bawang putih, garam, gula pasir, telur, penyedap.

\section{Proses Pembuatan:}

Pertama ikan tenggiri segar disiangi diambil dagingnya dan digiling. Kemudian wortel, daun bawang,bawang bombai diiris tipis. Selanjutnya lada, bawang putih, garam dan gula pasir dihaluskan dan dicampur dengan sayuran, daging ikan, tepung tapioca, telur sampai merata. Adonan kemudian dibungkus dengan kuit pangsit, diikat dengn daun kucai kemudian digoreng diatas api kecil. Setelah masak angkat dan dinginkan, kemudian dilakukan pengemasan.
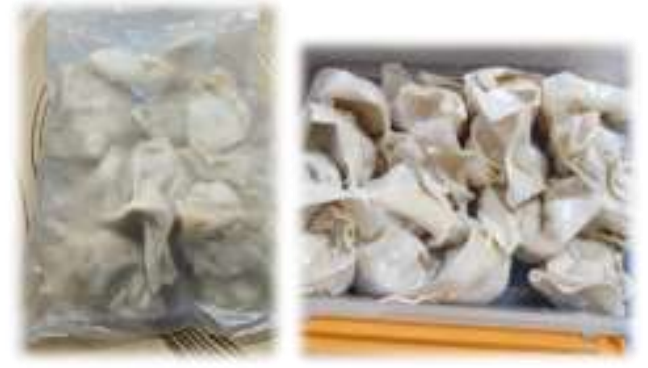

Gambar 5. Pangsit Ikan Tenggiri

Kegiatan ini didemonstrasikan kepada ibu-ibu nelayan Desa Muara Gading Mas yang seluruhnya berjumlah sekitar 15 orang yang terbagi dalam 3 kelompok binaan. Kegiatan demonstrasi olahan produk olahan ikan merupakan kegiatan utama yang dilakukan untuk memberi pengetahuan mengenai pengolahan ikan guna meningkatkan konsumsi ikan yang memiliki kualitas yang baik. Pengetahuan yang diberi meliputi teknik pemilihan bahan, pencucian, sampai pegemasan produk dan tahapan pembuatan produk. Demonstrasi ini diperlukan karena produk diversifikasi ikan ini belum diproduksi di kelompok nelayan Desa Muara Gading Mas. Demostrasi dilakukan dengan cara memberikan pengetahuan dan praktek olahannya. Varian olahan ikan ada empat, yaitu bakso ikan, kerupuk ikan, pindang presto dan pangsit ikan. Hal terpenting yang didapatkan setelah dilakukannya demonstrasi yakni ibu-ibu nelayan mengetahui cara pembuatan bakso ikan, kerupuk ikan, pindang presto dan pangsit ikan dan memahami cara mempromosikannya. Masyarakat sangat antusias dan merespon baik adanya kegiatan ini karena rasanya yang enak serta menambah wawasan mereka terhadap pengolahan perikanan. 
Pada dasarnya proses kegiatan pelatihan pembuatan olahan produk ikan yang bernilai ekonomis dapat terlaksana dengan baik dengan prosentase keberhasilan sekitar $\pm 90 \%$, hal ini diindikasikan dengan tercapainya tujuan utama yakni mengahasilkan produk olahan ikan yang lebih bernilai ekonomis jika dibandingkan dengan menjualnya dalam bentuk ikan segar. Produk yang telah dihasilkan oleh ibu -ibu partisipan terdiri dari: bakso ikan, kerupuk ikan, pindang presto dan pangsit ikan. Walaupun kegiatan ini dirasa cukup berhasil namun ada beberapa catatan untuk perbaikan kedepannya seperti halnya dalam kegiatan ini belum sampai kepada pengujian laboratorium terkait peningkatan kandungan gizi produk hasil olahan, sehingga kedepan perlu pendampingan sampai dengan pengujian laboratorium sehingga apabila nantinya akan dipasarkan kepada konsumen akan memberikan keyakinan terhadap kuaitas dari produk yang telah dihasilkan.

Pada akhir pelatihan peserta memperoleh informasi yang berguna untuk menambah pengetahuan mereka tentang produk olahan ikan, yang selama ini hasil tangkapan ikan para nelayan hanya dijual dalam bentuk ikan segar dengan nilai ekonomis yang masih rendah. Rangkaian kegiatan pengabdian tidak hanya meliputi pelatihan terhadap pembuatan produk olahan, namun juga edukasi proses digitalisasi proses pemasaran yang dilakukan secara online, sehingga mereka tidak terkendala dengan proses distribusi produk sampai kepada konsumen.
Pemasaran produk olahan ikan dilakukan secara offline dan online. Promosi secara offline dengan melakukan pembagian tester sebelum penjualan produk dilakukan. Hal ini bertujuan untuk mengenalkan produk dan melihat tingkat penerimaan oleh calon konsumen terhadap produk sedangkan promosi secara online dapat dilakukan dengan membuat akun di media sosial seperti facebook dan Instagram. Media sosial ini sebagai sarana untuk menginfokan lokasi penjualan. Pembuatan media sosial juga diharapkan semakin banyak masyarakat yang mengetahui dan tertarik untuk membeli produk olahan masyarakat nelayan Desa Muara Gading Mas. Penggunaan promosi produk melalui online penting dilakukan karena lebih menarik niat pembelian untuk konsumen.

\section{SIMPULAN}

Pengabdian yang telah dilakukan berupa edukasi masyarakat nelayan melalui pengembangan produk olahan ikan bernilai ekonomis tinggi di Desa Muara Gading Mas Kec. Labuhan Maringgai Kab. Lampung Timur telah terlaksana dengan baik dan lancar sesuai dengan jadwal dan mendapat tanggapan yang positif dari warga. Hal tersebut dibuktikan dengan respon warga dalam mengikuti demonstrasi yang dilakukan dengan alat dan bahan yang sangat mudah di dapat dengan harga terjangkau serta hasil produk dapat dijual dengan harga yang menguntungkan. Produk juga 
dikemas secara menarik untuk meningkatkan penjualan.

Melalui kegiatan ini diharapkan masyarakat nelayan mampu melakukan inovasi dengan diversifikasi produk olahan ikan yang bernilai ekonomis lebih tinggi sehingga diharapkan menaikan pendapatan ekonomi masyarakat dimasa pandemi.

\section{SARAN}

Saran-saran untuk program pengabdian masyarakat lebih lanjut antara lain: perlu dilakukan pendampingan kegiatan pemasaran seperti pembuatan merek dagang, sistem pengemasan yang menarik dan pemasaran ke pedagang besar yang potensial serta perlu dilakukan pengujian laboratorium terhadap nilai gizi produk olahan yang dihasilkan dan bila perlu didaftarkan di BPPOM sehingga memberi keyakinan kepada konsumen terhadap kualitas produk.

\section{UCAPAN TERIMA KASIH}

Ucapan terimakasih kami sampaikan kepada Lembaga Penelitian dan Pengabdian Kepada Masyarakat (LPPM) Universitas Saburai yang telah memfasilitasi kami dalam kegiatan PKM ini. Perngkat desa khususnya Kepala Desa Muara Gading Mas Bapak Wahyono serta masyarakat nelayan Desa Muara Gading Mas sebagai desa mitra atas respon dan partisipasinya dalam kegiatan ini sehingga semuanya berjalan dengan lancar.

\section{DAFTAR PUSTAKA}

[1] M. Rijal, "Diversifikasi Produk Olahan Ikan Bagi Ibu-Ibu Nelayan di Dusun Mamua Kabupaten Maluku Tengah,” J. Biol. Sci. Educ., vol. 6, no. 2, pp. 159 170, 2017.

[2] D. Safitri, W. Y. R., Irmawanty, and H. Hambali, "Pendampingan dan Pelatihan Diversifikasi Pengolahan Ikan Bagi IbuIbu Nelayan di Pulau Sembilan Kabupaten Sinjai," J. Biol. Sci. Educ., vol. 8, no. 1, pp. 122-130, 2019.

[3] I. Effendi and R. Wiyati, "Pelatihan Pembuatan Bakso dan Nuget Ikan Bagi Ibu Rumah Tangga Kampung Minas Barat Kabupaten Siak," J. Rural Urban Community Enpowerment, vol. 1, no. 1, pp. 61-66, 2019.

[4] R. D. Azzahra, "Implikasi Pandemi Covid-19 Terhadap Redaksi Force Majeure Dalam Perjanjian Bisnis," Kumpul. J. Mhs. Fak. Huk., 2021.

[5] M. N. Sari, F. Yuliasara, and M. Mahmiah, "Dampak Virus Corona (Covid-19) Terhadap Sektor Kelautan dan Perikanan: A Literature Review," J. Ris. Kelaut. Trop. (Journal Trop. Mar. Res., vol. 2, no. 2, p. 59, 2020, doi: 10.30649/jrkt.v2i2.41. 
[6] I. Natalia, "Pengaruh Pasar Saham Amerika Serikat, Tiongkok Dan Indonesia Selama Perang Dagang 20182020," Akurasi J. Stud. Akunt. dan Keuang., vol. 3, no. 2, pp. 95-108, 2020, doi: 10.29303/akurasi.v3i2.49. 